\title{
THE INTERACTION OF
}

INSTITUTIONALIZATION OF INFORMATION TECHNOLOGY \& INSTITUTIONAL ENTREPRENEURSHIP: AN IDEA OF A FRAMEWORK FOR THE APPLICATION OF INFORMATION TECHNOLOGY IN PUBLIC SECTOR FINANCIAL MANAGEMENT

Fikry Karim

Tadulako University, Diponegoro University Economics Doctoral Program Student, Jl. Prof. Sudarto, Tembalang, Kec. Tembalang, Kota Semarang, Jawa Tengah, Indonesia

Imam Ghozali

Diponegoro University, Jl. Prof. Sudarto, Tembalang, Kec. Tembalang, Kota Semarang, Jawa Tengah, Indonesia

Tarmizi Achmad

Diponegoro University, Jl. Prof. Sudarto, Tembalang, Kec. Tembalang, Kota Semarang, Jawa Tengah, Indonesia

\section{Puji Harto}

Diponegoro University, Jl. Prof. Sudarto, Tembalang, Kec. Tembalang, Kota Semarang, Jawa Tengah, Indonesia

\begin{abstract}
This article aims to provide an idea of a framework for implementing information technology in public sector financial management. This is based on the ongoing debate regarding the impact of information technology implementation on Government performance, including in the management of government finances. Through a literature review and understanding of the application of information technology in the context of Local Government in Indonesia, it was found that the concept of institutionalizing information technology was not sufficient to explain the benefits of implementing information technology on the performance of regional financial management, it was also necessary to consider the extent of the role of institutional actors that could potentially influence and have the power to legitimize and mobilize organizational resources to direct the institutionalization of information
\end{abstract}


The Interaction of Institutionalization of Information Technology \& Institutional

Entrepreneurship: An Idea of a Framework for the Application of Information Technology in Public Sector Financial Management

technology to explain comprehensively the variations in the implementation and benefits of implementing information technology in local financial management. As well as having implications for improving the process of implementing information technology in local governments, this article also opens up opportunities for future research development, particularly in relation to the role of information technology in public sector financial management.

Key words: Institutionalization of Information Technology, public sector financial management, institutional theory, Information technology of local Government.

Cite this Article: Fikry Karim, Imam Ghozali, Tarmizi Achmad and Puji Harto, The Interaction of Institutionalization of Information Technology \& Institutional Entrepreneurship: An Idea of a Framework for the Application of Information Technology in Public Sector Financial Management, International Journal of Management, 11(12), 2020, pp. 858-883.

http://iaeme.com/Home/issue/IJM?Volume=11\&Issue=12

\section{INTRODUCTION}

The application of information technology is an important part of financial management reform in developing countries, because it is a major component in building an integrated financial management information system (Peterson, 2006), and is one of the main issues in achieving successful implementation of performance-based budgets (A. Ho, 2007 ; Jordan \& Hackbart, 2005). However, even though it has the potential for high technical benefits (including automating the recording, reporting and management of public finances), information technology cannot always be optimally implemented by government organizations, is still seen as less useful and synonymous with resistance (El-Haddadeh, Weerakkody \& Al-Shafi, 2013 ; Greenfield \& Rohde, 2009) and tends to show negative results ( Hazlett \& Hill, 2003 ), especially in developing countries (Heeks, 2002, 2003), so that the existence of information technology does not guarantee the creation of public finance more comprehensive, transparent, accountable and legitimate (Dorotinsky \& Watkins, 2013).

The debate / differences in the results of these studies indicate the importance of further analysis of the institutionalization of information technology, because as stated by Kumar and Best (2006), one of the main causes of failure to realize the potential of information technology in developing countries is the low level of institutionalization. The concept of institutionalization is not identical, it even has a deeper meaning than the concept of implementation. Institutionalization is the process of forming or adopting and implementing new practices and internalizing them into normal organizational routines (Dambrin, Lambert, \& Sponem, 2007; Hasselbladh \& Kallinikos, 2000; Kostova \& Roth, 2002). Institutionalization in the context of information technology means the adoption of technology to transform old practices, carry out these practices to become organizational routines. Because routines basically describe organizational capabilities (Winter, 2003), the formation of routines can have an effect on performance (Cohen \& Bacdayan, 1994) .

Therefore, considering that specific research related to the institutionalization of information technology previously used a more dominant case study approach in business organizations (for example, Backouse, Hsu, \& Silva, 2006; Cousins \& Robey, 2005; Currie, 2004; Mark, 2007 ; Miscione, 2007; Swanson \& Ramiller, 1997; Wang \& Swanson 2007, 2008), then through a literature review and conceptual review based on institutional theory, this article aims to propose an idea of a framework for applying information technology in 
public sector financial management by considering interaction between Institutionalization of Information Technology \& Institutional Entrepreneurship.

Previous research on institutionalization of information technology used a newinstitutionalism perspective to investigate how information technology was introduced, developed and had legitimacy in the environment, so that it was eventually widely adopted by various users. Because the new-institutionalism perspective considers institutionalization to take place within the organization (Powell and DiMaggio, 1991), these studies do not specifically discuss phenomena at the organizational level, so the impact of institutionalization at the organizational level has not been explained. In addition, the differences in the impact of information technology on government above show that the institutionalization of information technology in government financial management practices is not an independent process. The old-institutionalism perspective views institutionalization as occurring at the organizational level (Powell and DiMaggio, 1991). Technology that has been legitimized at the organizational level, although adopted and maintained, faces a very central dynamic of interest in the internal organization (Greenwood and Hinings, 1996), so that even though it is in the same environment, it is the internal dynamics of each organization that are not identical that can cause impacts. the application of information technology is different.

This is also in accordance with the opinion which states that from an institutional perspective, change is a dynamic process and the results depend on a coalition of organizational actors ( Dillard, Rigsby, \& Goodman, 2004 ; Fligstein, 1997 ; Seo \& Creed, 2002 ). It is these actors who are influential and have the power to legitimize and mobilize organizational resources to direct the internalization of new practices. Because this phenomenon is still not explained in previous scientific articles, the main contribution of this article apart from explaining the extent of the institutionalization of information technology in public sector financial management, also considers the activities of institutional actors ( entrepreneurship ) and their interaction with the institutionalization process, because with an understanding of This interaction can further explain the variation of institutionalization and the impact of the application of information technology on public sector financial management, which is presented based on a literature review using the context of the application of information technology in local governments in Indonesia.

The next part of this article consists of 4 parts, namely the second part explaining Institutional and Institutionalization theory. The third part describes the framework for implementing information technology in public sector financial management in the context of the Indonesian Regional Government, including the role of institutionalization of information technology and institutional entrepreneurship and their interactions. The fourth part is the conclusions and research opportunities in the future.

\section{INSTITUTIONAL THEORY}

The institutional theory is the dominant perspective used in organizational and management research (Greenwood, Oliver, Sahin, \& Suddaby, 2008 ; Orlikowski \& Barley, 2001). This domination occurs because institutional theory offers a single paradigm for studying organizations (Suddaby, 2010). However, Scott (2005) states that the contribution of the creativity of social researchers makes institutional theory rich in perspectives, and is used to investigate social interactions between individuals (micro) to global (macro) frameworks. The strength of institutional theory lies in its ability to explain the deepest aspects and durability of social structures, observing the processes through which these structures become established as mandatory guidelines for social behavior (Scott, 2005). 
The Interaction of Institutionalization of Information Technology \& Institutional

Entrepreneurship: An Idea of a Framework for the Application of Information Technology in Public Sector Financial Management

Studies with an institutional perspective conducted from the late 1970s and early 1980s question why organizations tend to look alike (Greenwood, Hinings, \& Whetten, 2014). These studies resulted in a stream referred to as new institutionalism, with a major focus on legitimacy, fields, templates, and schema (Greenwood et al., 2008). Legitimacy is considered as the main concept in institutional theory (Barley, 2008 ), organizations and organizational actors try to gain legitimacy in their environment in order to be accepted and therefore ensure long-term sustainability ( Meyer \& Rowan, 1977 ) .

Organizations do not always carry out strategies, structures and processes to support increased performance, but are a reaction to efforts to accommodate external pressures and regulations (Frumkin \& Galaskiewicz, 2004). Organizations seek legitimacy from their environment, improve or maintain it (Suchman, 1995), although they must comply with formal and informal pressures (Oliver, 1997). These views emphasize that the dynamics of the organization is persistence, the organization always maintains its stability and adopts legitimate changes in the environment, so that new institutionalism views institutionalization as being at the level of the organizational environment (Powell \& DiMaggio, 1991).

Katsikas, Rossi, and Orelli (2017) state that institutional theory consists of various perceptions of organized human behavior, but it assumes that human actions are in some way limited by social structures which are the product of past social interactions. Institutional theory research investigates issues of competing values, power and influence, coalition, and informal structures, and is known as old institutionalism (Greenwood et al., 2014 ). These issues have always been the source of organizational dynamics, conflicts of interest and coalitions trigger internal changes, thus underlying the conclusion that institutionalization occurs at the organizational level (Powell \& DiMaggio, 1991).

The main concerns of institutional theory are the interaction of an organization with its institutional environment, the influence of social expectations on the organization, and the internalization of these expectations into the practices and characteristics of the organization. Organizational activities derive motivation from the importance of efforts to gain legitimacy, which in turn are influenced by social norms. In order to ensure its sustainability, an organization must interact with its environment in ways that are acceptable to various constituents in that environment. This assumes a collective understanding of what constitutes appropriate behavior.

Suddaby (2010) explains that to understand exactly how the system of institutional meaning is understood and interpreted in organizations, institutional researchers must adopt an internal perspective. Analysis must be carried out at the organizational level and views the organization as an interpretive mechanism that filters, decodes, and translates the semiotics of the broader social system ( Rao \& Giorgi, 2006 ) .

\subsection{Institutionalization}

According to Huntington (1965), institutionalization is a process through which organizations and procedures to have the value and stability. Berger and Luckman (1967 ) explain institutionalization by providing an example of the formation of 'social orders' (social rules), which are generated by humans to provide direction and stability in carrying out various activities. A social rule is needed by humans to move in a certain environment. Social rules provide guidelines for group members to behave in the same direction as group goals. The alignment of individual actions and group goals provides stability, which is so necessary for the group's long-term survival. However, social rules always follow the dynamics of human activities which are always developing, so that they undergo a 
reproductive process to become an integral part of the organization. A procedure that has stability, can function as a social rule that guides human or organizational activities.

Organization is a social system, goals or procedures tend to try to achieve establishment, so it is called institutionalized (Scott, 1995). Organizations with non-specific goals, inadequate procedures and technology tend to undergo institutionalization processes to achieve stability or stability. Goals become more specific or focused, supported by appropriate and relevant procedures and technology. Because individual actions follow applicable procedures, institutionalized procedures lead to more coordinated and controllable behavior in order to achieve social governance orderliness or specific organizational goals.

In the context of adopting a new practice, institutionalization is the implementation and internalization of new practices ( Kostova \& Roth, 2002 ), or an activity carried out to make certain practices the routine of everyday social life ( May \& Finch, 2009 ), to a certain point where a practice that consistently undergoes a process of socialization becomes habitual ( Parsons, 1991 ). One of the main functions of institutionalization is to organize the diversity of activities and relationships into an adequate coordination system, so that it can be managed and avoid conflict at the social level. Routines that have become habitual have standard procedures as a result of the interaction process of various organizational actors. Regulated procedures allow activities to be coordinated to achieve specific goals. An institutionalized organizational system has formal procedures that are developed as standards that regulate individual actions, as well as provide system characteristics. The existence of formal procedures to control individual behavior creates stability in the implementation of the system, which allows the system to be transmitted throughout the organization and to the next generation, without experiencing change.

Based on these perspectives, institutionalization can be viewed as a series of actions (processes) that aim to build new standardized and regulated practices to achieve stability in organizational structures and processes. Institutionalization includes the adoption or formation of new practices, their implementation as an organizational activity, and the integration of these practices into an integral part of the overall routine of the organization. A new practice is said to be institutionalized, if its implementation in the organization has certain characteristics, even though it is practiced by various types of individuals. A practice becomes an integral part of the main orientation system of a collectivity, because it gets acceptance and commitment. This is in line with the main idea of institutionalization studies which must reveal the entire institutionalization process, starting from how the implementation process is internalized to the actions and behavior of actors in an organization (Dambrin et al., 2007 ; Hasselbladh \& Kallinikos, 2000 ; Siti-Nabiha \& Scapens, 2005 ) .

\subsection{Information technology institutionalization}

The use of social theories in information systems research in the last two decades is to understand the social dynamics associated with information systems (DeVaujany, Carton, Mitev, \& Romeyer, 2014), or social dimensions related to the development and use processes. information technology (Jones, 2000). Institutional theory is one of the theories used to understand how institutions affect the design, use, and consequences of technology, both within organizations and between organizations (Orlikowski \& Barley, 2001). According to Weerakkody, Dwiyedi, and Irani (2009) the relevance of institutional theory in particular lies in the context of understanding the impact of internal and external influences on organizations that carry out various change agendas, especially those involving information technology as the trigger for change. Granovetter (1985) argues that an institutional perspective offers a better explanation of information technology innovation as a social phenomenon, predicting innovation adoption and adoption outcomes (eg, Edquist and 
The Interaction of Institutionalization of Information Technology \& Institutional

Entrepreneurship: An Idea of a Framework for the Application of Information Technology in Public Sector Financial Management

Johnson (1997); Teo et al. (2003). Institutional factors, such as regulations, culture, and market practices, are the driving force for organizations to adopt innovations that are currently popular in their environment. However, not all information technology innovations can be adopted globally, some of which do not develop, even fail.

Meta-theory conducted by Mignerat and Rivard (2009) on 53 articles using institutional theory found that this theory is used to examine phenomena related to information technology innovation, development and implementation of information systems, and the adoption and use of information technology. The focus of discussion in these institutionalization researches is divided into several themes, namely, the entire institutionalization process, certain parts of the institutionalization process, the relationship between the two institutionalization processes, and the role of the organizing vision in the institutionalization process.

\subsubsection{Entire institutionalization process}

Avgerou (2000) argues that information system development and organizational transformation are two different institutionalization processes and produce two different institutions. So that information technology innovation is not a trigger or part of the flow of organizational change, but interacts with it. The ongoing introduction of information technology in organizations tends to be more due to the processes and actors associated with it.

Information technology innovation and organizational practices have their own mechanisms and elements of legitimacy, but at very different levels of institutionalization. The institutional elements of information technology can be identified from the values, knowledge, industrial and professional networks, and established regulations (Avgerou, 2000). The values possessed by information technology cause its institutionalization process to continue to gain momentum and become a characteristic of modern organizations, while the most influential form of organization (hierarchical bureaucracy) continues to face challenges and it is difficult to gain legitimacy like that of the old model. So that the interaction between information technology innovation and organizational change can be conceptualized as a dual process consisting of institutionalizing information technology and de-institutionalizing existing organizational structures and practices ( Avgerou, 2000 ). The adoption and diffusion of an innovation initially occurs not only based on the promised technical benefits, but also due to pressure from influential actors. Through institutionalization, innovation is adopted and maintained because of the legitimacy it has, regardless of whether the innovation produces the promised technical benefits or not, and without having to continue to depend on individual power ( Avgerou, 2000 ).

Studies in this area show that the institutionalization of information technology in many ways continues because of its institutional strengths, it does not depend on its contribution to the process of organizational change. Information technology is institutionalized within the organization when accompanied by organizational changes. One of the direct consequences of using information technology is a change in internal processes. Old activities must be replaced by new technology-based models. The institutionalization of new practices must involve de-institutionalization of old practices or dominant organizational forms or changes in structure. This means that information technology innovation alone does not necessarily contribute to the organization without being accompanied by changes in the structure or practices that have been carried out by the organization. The effectiveness of change is more optimal if it is driven by actors through the creation of a common vision, obtaining agreement from various stakeholders, which ultimately strengthens the legitimacy of information 
technology. Initially, the institutionalization of information technology was aimed at increasing efficiency and strengthening the coordination and control mechanisms of the bureaucracy. Furthermore, the legitimacy of information technology is used to modify the bureaucratic organizational structure, so as to create new organizational forms.

\subsubsection{One part of the process}

In contrast to the initial perspective of institutional research which considers the institutionalization process to occur after the adoption decision is made, Jepperson (1991) states that institutional processes occur from the beginning of the diffusion of innovation, and choices are made in the context or by reference to these processes ( Swanson \& Ramiller, 1997 ). This view emphasizes that institutional processes can reduce perceptions of the uncertainty surrounding innovation, making it possible to make local rationalities or express choices ( WL Currie, 2004 ).

The study of WL Currie (2004) investigated the discourse of disseminating a new information system innovation, namely application service provision (ASP), until it was widely adopted. The popularity of ASP is built on interests that influence the information technology sector, marketed through various forms of communication, so that it becomes popular and gains legitimacy, thereby increasing the potential for adoption by various users. ASP communications are built on various themes to attract users' attention, with various messages about the benefits of the latest information technology for business and the economy. These messages are popularized by influential institutions, which have different interests, including international government organizations, large companies in the information technology sector, business analysts, academic institutions. All of them aim to benefit from the growing ASP phenomenon. These movements make the basis of ASP support broader, and become part of the community discourse among business actors in the information technology sector, thereby increasing the legitimacy of ASP. The basis of legitimacy as the basis for adoption can determine the level of institutionalization of new technological innovations. When information system innovation has legitimacy, formal evaluation tends not to be carried out.

This study shows that the institutionalization of information technology is closely related to a persistent legitimacy process. Initial institutionalization in the form of information technology innovation or standards for the development of information technology innovation was triggered by influential parties who have an interest. Information technology standards or products have the opportunity to develop if they receive support at the beginning of development from these parties. Mainly to form initial perceptions about new innovations, through propaganda and the use of power, which is the initial legitimacy process. The continuity of institutionalization until it is widely adopted is determined by the growth of legitimacy. The consistent use of new product innovations by influential parties will increase the basis for the legitimacy of the innovation, so that it is widely adopted as an appropriate thing. In the case of standard institutionalization, the consistency of using power on certain organizational members to apply the proposed standards will increase the chances of acceptance of these standards by all entities in the environment so that it becomes a new authoritative source for information technology innovation development practices.

\subsubsection{The relationship between the two institutionalization processes}

Advances in information technology cannot always be followed by a transformation of the business model, it can even end in failure. In-depth analysis of successful companies reveals that changes in business models occur in response to market competitive pressures and social expectations ( Cousins \& Robey, 2005 ). Study Cousins and Robey (2005) about the 
The Interaction of Institutionalization of Information Technology \& Institutional

Entrepreneurship: An Idea of a Framework for the Application of Information Technology in Public Sector Financial Management

relationship between the two processes of institutional found that the structure and business model of electronic metal exchane interact with the pressures of efficiency and legitimacy. Although the efficiency is made possible by internet technology which provides greater transparency of information and public access, the public metal exchanges model has a lower resilience than the private exchanges model. This is because traders consider private exchanges to be more legitimate. This model allows for the continuation of traditional relationships involving trust and privacy, which is not possible in the model of public metal exchanges.

Institutional analysis cannot ignore the opposing forces that create clash of values ( Avgerou, 2000 ; Robey \& Boudreau, 1999). Because the interaction between these forces can explain various organizational responses to the institutional environment. As Oliver (1991) argues that organizations do not always have to compromise on environmental pressures to gain and maintain legitimacy, but can avoid, reject, and even control the environment in order to comply with organizational demands. The possibility of a pluralistic environment, causes opposing institutional values to produce contradictory organizational responses ( Meyer \& Rowan, 1977 ) .

Another study investigating the conflict between two institutions was conducted by Miscione (2007) . The study analyzed the interaction between a health insurance system that uses the telemedicine system, a health information system created by politicians and academics, and local public health practices. A new system was introduced to improve health conditions by promoting modern science-based medical practices, in an area that already has well-established traditional medical practices. Miscione's (2007) study concluded that organizational change can be successful if it places medical knowledge and telemedicine systems within the boundaries of different practices and sources of accountability. The development of a new health system must integrate the social context of local communities and their diversity as local institutions. It is very important to know what the information system considers to be taken for granted and to analyze the local implications of the changes the telemedicine system seeks to achieve.

Research on this theme shows that institutionalization of an information technology innovation is not just technical rationality, but must consider contextual rationality. Technical rationality alone tends to end in failure, efficiency and effectiveness cannot be achieved. Some of these studies indicate that only practices that have strong and broad legitimacy, can be fully institutionalized, which is shown by becoming routine in organizations or society. A new practice needs to have consistent legitimate support in order to guarantee the continuity of its institutionalization. The development of new practices must be done contextually. Integrating old institutions in the innovation development process. If you are faced with old practices that are conflicting, it requires a process of shifting the focus of legitimacy from old to new practices.

\subsubsection{The role of organizing vision in the institutionalization process}

Organizing vision is society's main idea for the application of information technology in organizations ( Swanson \& Ramiller, 1997). Information technology innovation always represents an organizational form, because innovation means a new organizational design. Changes in roles, responsibilities, relationships, lines of command, control mechanisms, work processes and workflows. Thus, an organizing vision for information systems innovation is a vision to organize in a certain way so that there is integration and utilization of information technology in organizational processes and structures. 
Swanson and Ramiller (1997) explain that information technology development carried out as part of the implementation of an organizational vision has legitimacy as an element of good organizational practice. Legitimacy is obtained by linking information technology with priority business functions. For example, "client-server" technology is associated with employee empowerment issues, while "groupware" and workgroup computing are associated with team-based work processes, "outsourcing" information systems is associated with downsizing ( Swanson \& Ramiller, 1997 ) .

The goals of information technology innovation in public organizations must be clear and specific. The contradiction between political and social goals will lead to different interpretations between various groups (W. Currie \& Guah, 2007). These differences in objectives must be consolidated, as they have a direct impact on the formulation of operational policies. Information technology innovation does not only mean computerization of old practices, but involves the transformation of the practice itself. If computerization does not have a significant impact on improving performance, the transformation that does not work will also have the same consequences for the organization.

Research on this theme confirms that organizing vision is a vital element in institutionalizing information technology innovation, because it has the ability to initiate and maintain institutionalization momentum. Vision serves to introduce the ideas and benefits of information technology innovation on offer. Furthermore, provide and maintain the confidence to adopt and use these innovations in a sustainable manner. The media and actors used to carry out this strategy must have strong legitimacy, in order to get serious attention from the public.

The information technology institutionalization studies presented above provide a detailed explanation of how information technology is widely institutionalized in various organizations. An information technology innovation is adopted by a variety of different organizations in the environment, because of the influential actors who have an interest in the new technology. It is the activities of these actors (institutional entrepreneurship) that allow the legitimacy of a new innovation to increase, so that it is finally accepted and used widely in the environment.

\subsection{Institutional entrepreneur}

Institutional entrepreneurs (institutional actors) are actors who have resources, socio-political expertise, and social position (Dacin, Goodstein, \& Scott, 2002). Institutional entrepreneurship is the activities of institutional actors who have an interest in certain institutional arrangements and utilize resources to create new institutions or transform existing ones (Maguire, Hardy, \& Lawrence, 2004). Institutional actors and their entrepreneurial activities are directly related to institutional change. Institutional change is a process that is political in nature, so that the resulting institutional form reflects the power and interests of organized actors and the mobilization of surrounding actors, who support, oppose, or otherwise struggle to influence it (Dillard et al., 2004 ; Fligstein, 1997 ; Seo \& Creed, 2002). Institutional actors carry out entrepreneurial activities to create new institutional configurations in order to realize their main interests in new institutions, or to transform old institutions (Fligstein, 1997 ; Rao et al., 2000). Maguire et al. (2004) concluded that the main issue in institutional entrepreneurship lies in the relationship between interest, agency, and institutions and aims to explain how a new institution is formed.

In the context of information technology, Wang and Swanson, (2007) argue that institutionalization of a new information technology innovation really requires the role of actors with an interest in moving the institutionalization of this technology in the 
The Interaction of Institutionalization of Information Technology \& Institutional

Entrepreneurship: An Idea of a Framework for the Application of Information Technology in Public Sector Financial Management

environment. New technology requires synchronizing the actions and pooling of interests of various actors, albeit temporarily, to support the diffusion of new technologies in the marketplace. The formation of these arrangements at the same time indicates that new technology is gaining social acceptance, so that it can develop and be institutionalized in the environment ( Gosain, 2004 ; Kling \& Lacono, 1989). According to Fligstein (2001) these arrangements are institutional, because they produce social relationships between companies that play a role in forming new markets for the innovations to be launched, thus enabling them to survive.

Wang \& Swanson (2007) emphasized that the formation of a market for a new technology really needs institutional arrangements, so that its existence and characteristics can be realized in the environment. These arrangements do not become the monopoly of the initiators of innovation, but involve new actors, who have resources and interests, who see various opportunities from new technological aspects to be institutionalized. The realization of these opportunities is determined by the collectivity to legitimize and mobilize institutional entrepreneurs (Wang \& Swanson, 2007). Legitimate technology motivates various parties to use their resources in developing new technology, so that it is widely accepted, and can realize the various opportunities that have been identified along with the wider use of new technology.

Information technology institutionalization at the organizational level can have a different mechanism with the environmental context ( Tolbert \& Zucker, 1996), but activities to legitimize and mobilize still have a significant role. At the organizational level, the adoption of information technology is triggered by influential actors, but its legitimacy makes information technology continue to be used, regardless of the realization of its technical benefits and does not depend on individual power ( Avgerou, 2000 ). Information technology institutionalization within the internal organization does not take place independently, because the application of information technology is always synonymous with change. According to (Avgerou, 2000 ) institutionalization of information technology within an organization will interact with organizational change, not trigger change.

Referring to the perspective of Tolberg \& Zucker (1996), information technology which is fully institutionalized at the organizational level tends to have a low variation in implementation, even though the character of its adopters is very diverse. However, information technology practices are integrated in an organizational context, due to the actions of individuals to activate it through a generative mechanism ( human agency), and then experience reproduction in the long term (May \& Finch, 2009). Human agency can strengthen the integration of new practices into the existing system, or if there is resistance in the organization, the agency becomes an obstacle to the development of integration. Human agency can cause the use of information technology to be adjusted to the dominant interests, so that variations in implementation can occur.

\section{INFORMATION TECHNOLOGY APPLICATION FRAMEWORK IN PUBLIC SECTOR FINANCIAL MANAGEMENT}

In public sector organizations, accountability is the main objective of performance measurement, and historically the focus of performance measurement has been on financial accountability or efficiency (Heinrich, 2003). The use of qualitative and quantitative measures can overcome the trade-off problem between efficiency (short term) and effectiveness (long term) Verbeeten (2008) . Quantitative performance is quantitative aspects (such as use of resources, amount of output produced, and efficiency), while qualitative 
performance is operational quality and strategic capacity (such as accuracy, innovation and long-term effectiveness) ( Carter, Klein, \& Day, 1992 ) .

Effectiveness and efficiency are common aspects of performance measurement. Effectiveness provides information on how well the organization operates to achieve its goals, while efficiency indicates how well the organization uses its resources to achieve goals. An assessment of the effectiveness and efficiency is needed to identify the problems faced, whether they are improving or getting worse. Studying the various relationships between the various relevant performance measures achieved in order to understand the causes or factors that contribute to success or the causes of failure, and find solutions for improvements or future performance enhancements. Determine what to do and who should do better in order to improve performance.

Government Regulation number 12 of 2019 concerning regional financial management confirms that good regional financial management is transparency, accountability, and participatory. Local governments must be able to create a regional financial management system that suits local needs, but is still in the construction of national regulations, and reviews the system continuously with the aim of realizing effective, efficient and transparent regional financial management. The performance measurement that is carried out must be able to assist the Regional Government to be able to carry out improvements in regional financial management functions in a sustainable manner. The quality of planning and budgeting is getting better, guaranteeing the orientation of the allocation of resources towards the achievement of the objectives of the Regional Government. Controlled budget execution and administration ensures that budget allocations are used effectively and efficiently, so as to achieve the desired targets, in accordance with the objectives set. Accountability for the use of budgets that meets applicable standards increases public trust in local governments, thereby motivating them to actively participate in regional development.

Law number 33 of 2004 concerning Central and Regional Financial Relations, Article 102 instructs regions to organize a regional financial information system (SIKD). This system must provide financial information, including the APBD and Regional Financial Reports in an open manner and can be accessed by the public. Furthermore, in Government Regulation (PP) Number 56 of 2005 concerning Regional Financial Information Systems, it explains that SIKD is a system that documents, administers, and processes regional financial management data and other related data into information presented to the public and as material for decision making in the framework of planning, implementing, and reporting the accountability of local governments.

The implementation of SIKD aims to assist Regional Heads in preparing regional budgets and regional financial management reports, formulating regional financial policies, evaluating regional financial performance, providing regional financial statistical needs, presenting Regional Financial Information openly to the public, and supporting the provision of Regional Financial Information required in SIKD nationally. To achieve these goals, the implementation of SIKD includes the presentation of budget information, budget execution, and regional financial reporting produced by the Regional Financial Management Information System (SIPKD) through the official website of the Regional Government (Article 13). Elucidation to PP 56/2005 defines SIPKD as a series of processes and procedures carried out by Local Governments in the framework of budget preparation, budget implementation and regional financial reporting. Local governments have the responsibility to provide comprehensive financial information to the public. This must be achieved through the development and utilization of advances in information technology to improve the ability to manage regional finances, thus opening opportunities for various parties to access, manage 
The Interaction of Institutionalization of Information Technology \& Institutional

Entrepreneurship: An Idea of a Framework for the Application of Information Technology in Public Sector Financial Management

and utilize information quickly and accurately to further promote the realization of a clean and transparent government.

Since the enactment of PP 56/2005, all local governments have used special software for regional financial management. Of the 542 local governments, 440 of them used applications obtained from the Indonesian Financial and Development Supervisory Agency (BPKP), 50 local governments used applications from the Ministry of Home Affairs (Kemendagri), the rest developed applications independently (Hermawan and Festina, 2014; BPKP RI, 2020 ). The provision of regional financial management applications by BPKP and the Ministry of Home Affairs is a form of Government support to accelerate the application of information technology.

The widespread application of information technology in regional financial management has not had a homogeneous impact on the performance of regional financial management. When viewed from the Summary of Audit Results for Semester 12019 (IHPS 1 2019) by the BPK, until 2018 the Regional Governments that obtained the WTP opinion were 79\% District Governments, 90\% City Governments, and 94\% Provincial Governments. The IHPS 12019 shows that since 2014 there have been 52 Regional Governments that have experienced an increase in opinion, but there are 15 Regional Governments that have experienced a decline in opinion.

The BPK audit revealed that there are still weaknesses in the internal control system in the form of inaccurate or inaccurate recording for 475 Local Governments, preparation of financial reports that do not comply with the provisions of 339 Local Governments, inadequate Accounting and Reporting Information Systems (SIAP) in 197 Local Governments, late reports and weak human resource support for SIAP in 30 LGs. In addition, there were 4,001 non-compliance issues with laws and regulations, the financial impact of which reached Rp. 2.19 trillion. These findings are identical to the functions of information technology, which should not happen if the application of information technology is carried out consistently. These findings are consistent with a survey conducted by UNDESA (2014 ), which shows that consistency of application is one of the main aspects that hinders progress in the application of information technology in the government sector in Indonesia.

Meanwhile, information technology research in the context of regional financial management in Indonesia is generally related to its impact on financial reporting. Research that has been done are the relationship of information technology with the quality of financial reporting information (eg, Anggriawan and Yudianto, 2018), reliability and timeliness of financial reporting (for example, Jauhari, Sari, and the Gods, 2019), the quality of the financial statements ( For example, Yuliani and Agustini, 2016; Muda et al, 2017; Rahman and Fachri, 2018; Furqan et al., 2020). However, these studies are generally related to the use or application of information technology. The institutionalization aspect, which describes the level of actual use of information technology in aspects of regional financial management, has never been implemented. This then leads to the need for a framework for the application of information technology in public sector financial management, so that it can explain more comprehensively how information technology is used and what factors cause variations in the role of information technology on regional financial management performance through the framework built. based on the interaction between the institutionalization of information technology and institutional actors therein ( Institutional entrepreneur ). 
Fikry Karim, Imam Ghozali, Tarmizi Achmad and Puji Harto

\subsection{Institutionalization of Information Technology Interaction with Institutional Entrepreneurs}

The interaction of information technology institutionalization with institutional entrepreneurs can be seen from the extent of the mobilization mechanism and the dynamics of legitimacy which can be explained as follows:

\subsubsection{Mobilization Mechanism}

Mobilization is a process whereby a social unit quickly gains control over resources (economy, political support or commitment) that were not previously controlled (Etzioni, 1968 ). In the context of information systems innovation, mobilization includes the activities of recruiting participants, stimulating motivation, and managing their resources (Wang and Swanson, 2007). Meanwhile, according to Dillard et al. (2004), mobilization is the allocation of human and material resources to facilitate or prevent action, and to support or hinder the development of structures of legitimacy and significance. These definitions indicate that mobilization tends to be a political process related to institutional arrangements. The actors adopt certain strategies to control resources and use them to carry out the desired institutional arrangements. An institutional change is a response to the desire and creativity of the actor ( agency ), the resources needed, and depending on the availability of opportunities ( Dorado, 2005 ). In conditions of change that must be carried out due to regulatory pressures, agency and resources are the determinants of the change process.

In this context, mobilization includes controlling the involvement of actors and their resources to support or influence the formation of new practices. Mobilization of support and acceptance that leads to the formation of new institutional arrangements can follow one of three different processes, namely accumulation, leverage, or convening ( Dorado, 2005 ).

- The process of accumulation is that support and acceptance arise when the possibility of the uncoordinated actions of various actors converge ( Ven \& Garud, 1993 ). This process is generative, in which a new innovation emerges and develops through the growth of a number of events involving the important roles of a number of actors with various backgrounds and in a long period of time. Institutional arrangements, resource formation, and technical economic activities are key components of this process (Ven \& Garud, 1993). An unplanned process, taking place randomly and voluntarily, but going in the same direction. This indicates a change that may occur, but over a long period of time.

- Leverage process means that support and acceptance occur because they are mobilized by actors who have political expertise (Rao, 1998). Actors with political expertise are the driving force behind this process, with expertise in framing and convincing others of the need for change. This indicates that change has predetermined goals and is directed at the desired aspects. Specifically, institutional actors identify opportunities, framing issues and mobilize constituents and resources on efforts based on these opportunities.

- The convening process means institutional change that is moved by creating collaborative arrangements ( Lawrence, Hardy, \& Phillips, 2002). This process is a collaborative process that requires high involvement from the participants and provides a broad collaborative impact in the environment.

The mobilization process interacts with the agency types of actors to produce institutional change (Dorado, 2005). Human agency is a temporary attachment constructed by actors from different environmental structures to social interactions to reproduce or transform an 
The Interaction of Institutionalization of Information Technology \& Institutional

Entrepreneurship: An Idea of a Framework for the Application of Information Technology in Public Sector Financial Management

institution. Temporary attachments determine how the habits, imaginations and judgments of the actors maintain or transform institutions. Agency is influenced by the orientation of the actors. The orientation includes past, present, and future.

Resource mobilization has the potential to maintain or increase the use of information technology, if its application is supported. On the other hand, limiting resource support can cause the use of information technology to decline. Directing resource mobilization towards specific uses, reduces the role of information technology. Information technology that does not receive the support of the resources it needs consistently, cannot maintain its functions optimally, and can even fail in the long run.

\subsubsection{Legitimacy Dynamics}

Suchman (1995) defines legitimacy as a general perception or assumption that the actions of an entity are in accordance with the norms, values and beliefs recognized in a social system construction. Meanwhile, according to Dowling and Pfeffer (1975), legitimacy is the consistency of social values of organizational activities with general norms of behavior that are recognized in the broader social system. A definition with a different perspective was put forward by Weber (1958), where organizational legitimacy is the consistency of organizational activities with their structure and rules.

These definitions indicate that the organization always seeks to adapt social practices and values that are reflected in it with the values recognized in its environment. This suitability is needed to justify the role of the organization in the social system, thus ensuring a sustainable supply of resources ( Ashforth \& Gibbs, 1990 ). Legitimacy from an external perspective is important for maintaining organizational stability, thereby ensuring the achievement of its long-term goals. The third definition means that the organization must transform relevant environmental values into more specific value standards as a reference for activities in its internal environment. This means that the organization legitimizes its activities through the internal rules it makes. Because the organizational structure reflects the division of functions and authorities in carrying out the organizational strategy, the linkage of activities to the structure will legitimize these activities. Changes that occur in the norms that apply in the social environment will trigger changes at the internal level of the organization. According to Ashforth and Gibbs (1990) these changes will drive legitimacy dynamics within the organization. The organization must evaluate its goals, structure and practices in order to keep it fit with its environment.

Ashforth and Gibbs (1990) argue that the dynamics of legitimacy are reflected in the approach and objectives of legitimacy. Substantively, the organization can make real and material changes to its objectives, structure, and processes or practices to maintain or increase its legitimacy. However, if the old system has been established, the organization can show symbolic changes. Practices can appear to conform to environmental norms while still pursuing old goals. Suchman (1995) indicates the dynamics of legitimacy from the choice of the focus of legitimacy on the actions or character (essence) of the organization, and legitimacy goals that are episodic or transitory (temporary), or permanent (long lasting ). Organizations can legitimize certain and temporary practices, or carry out legitimacy to highlight the long-term character of the organization.

The dynamics of legitimacy can be identified from the forms of legitimacy achieved, because each form of legitimacy has a different level of depth. Previous legitimacy studies have suggested forms that include regulative legitimacy, pragmatic legitimacy, moral 
(normative) legitimacy, and cognitive legitimacy ( Kaganer, Pawlowski, \& Wiley-Patton, 2010 ; Suchman, 1995 ).

- Regulative legitimacy is generated by aligning new practices with prevailing formal rules.

- Pragmatic legitimacy lies in the individual calculations of the organization's direct audience or parties that make direct exchanges with the organization (Suchman, 1995). Pragmatic legitimacy is self-interest, for example whether a certain activity provides benefits to those who run it.

- Normative legitimacy is based on judgments about whether a new practice conforms to, or promotes moral values and norms that are considered important in a particular social environment (Kaganer et al., 2010 ). Certain practices will be exercised or have legitimacy, because they are considered as the right thing to do, have conformity with recognized environmental values, even though they do not benefit the evaluator. This legitimacy has more stability, because in addition to outcomes, aspects that are legitimized include structures and procedures to produce these outcomes. So that the organization is more deeply legitimate, because it involves the results and the methods taken.

- Cognitive legitimacy refers to the level of dissemination of information or knowledge about a new business or practice among the social community (Aldrich \& Fiol, 1994 ) and the suitability of this knowledge with elements of the institutional framework (Suchman, 1995). The more popular a practice is in the social environment, the higher the legitimacy of the practice.

As forms of legitimacy shift from pragmatic to cognitive, legitimacy becomes more difficult to obtain and manipulate. When it reaches stability (taken for granted), legitimacy becomes deeper and has better resistance. Hannan and Freeman (1986) argue that when a practice has reached the taken for granted stage, the practice becomes a standard in the environment. Practices that can be taken for granted, reflect a level of acceptance and deep conviction, as well as a greater opportunity for commitment to carry them out.

The dynamics of the legitimacy of a new practice that occurs in the organization is determined by the assessment or perception of influential actors in the organization regarding the practice that must be carried out and the desired context of legitimacy. If the implementation of new practices is a necessity and is considered to have benefits for the organization, but organizational actors do not want significant changes to the stability of the old structures and processes that have been achieved, then partial actions are taken to legitimize new practices. Actions aim to demonstrate to specific constituents that the desired change is taking place. Change tends to occur symbolically, rather than substantially. New practices are adopted without making changes to old routines. If a new practice causes a change, then the change occurs partially by making the new routine separate from the existing routine. In these conditions, new practices are legitimized pragmatically. This phenomenon is considered an inseparable attribute of organizational and institutionalization practices (Modell, 2003 ), although there are certain practices that cannot be carried out separately from routine organizational activities, because they are directly related to all activities and organizational structures ( Covaleski \& Dirsmith, 1988 ) .

Based on this opinion, local governments can use regulations to legitimize new practices, so that all members of the organization continue to run. Activities that focus on the adoption of information technology in accordance with regulatory demands are an indication that legitimacy lies in the existence of regulations to legitimize new practices. The depth of legitimacy is determined by the scope and orientation of the use of the information system. The wider the scope of the use of the system in organizational activities, and the 
The Interaction of Institutionalization of Information Technology \& Institutional

Entrepreneurship: An Idea of a Framework for the Application of Information Technology in Public Sector Financial Management

permanent orientation towards building the character of the organization, the more it is in the form of legitimacy. Practices are carried out because they are obligations, regardless of the value and benefits In addition, the legitimacy of practice is built by linking recognized values in the environment, namely transparency, participation and accountability. So that practices are carried out because they promote or have conformity with environmental values.

To provide a more concise description of how the interaction between information technology institutionalization and institutional entrepreneurship in increasing the successful application of information technology in public sector organizations can be seen in Figure 1 below:

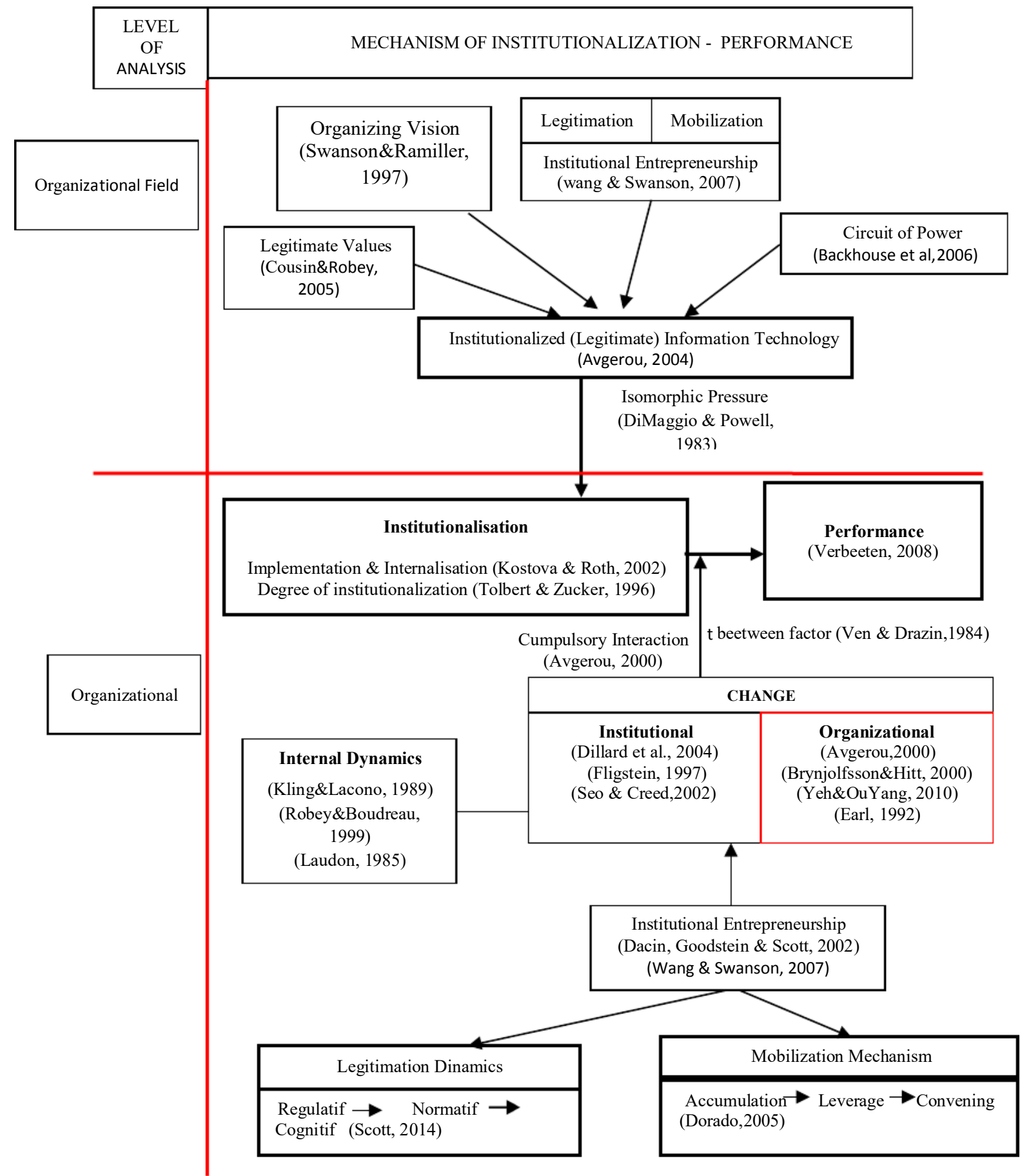

Figure 1 
The interaction between institutionalization of information technology and institutional entrepreneur in increasing the success of the application of information technology

\subsubsection{InformationTechnology Institutionalization and Institutional entrepreneurship in local government financial management}

Institutionalization is considered one of the causes for the negative impact of information technology that tends to occur in public sector organizations (Hazlett \& Hill, 2003; Heeks, 2002 , 2003). Information technology studies with a more specific analysis, using variables that reflect the actual use of information technology, prove the positive impact of information technology on organizational performance ( Devaraj \& Kohli, 2003 ). In addition, Devaraj \& Kohli (2003) argued that there are moderating variables, such as business process reengineering (BPR), which contribute to the relationship between information technology and performance. Although information technology and organizational practices (eg BPR), each have an impact on performance, together they can have a more significant impact (Devaraj \& Kohli, 2000). In this context, performance is the result of a close match ( fit ) between these two factors (Ven \& Drazin, 1984 ; Venkatraman, 1989 ). Better performance is realized when there is congruence between factors, so that the impact of information technology on performance is determined by the implementation of other organizational processes (Devaraj \& Kohli, 2000). One appropriate approach to expressing congruence between factors is to use the terminology of interaction (Ven \& Drazin, 1984), and the interpretation of congruence is more consistent when using it as moderation (Venkatraman, 1989).

In highly regulated government organizations, changes to the internal processes of the organization cannot be done easily. The attachment of local government organizations to the institutional environment, namely regulations, norms and habits that influence organizational behavior and its results, so that organizational change is identical to changes in these institutions. Institutional change can only occur because of changes in legitimacy and there are resources that drive change.

Institutional change is synonymous with agency of institutional actors, because agency activities of these actors drive the change process. Agency can produce changes in line with the use of technology if it is carried out by actors who support these changes. On the other extreme, agency can represent resistance to change, because information technology has the potential to change old habits. The agency scope can be in the form of full support to create the suitability of technology and organizational processes, by deeply legitimizing new practices based on information technology and mobilizing human resources and budgets (strategically) that facilitate the necessary changes to enforce these practices, or limit legitimacy and mobilization to the automation of old practices.

Devaraj and Kohli (2003) study on the use of information technology in hospitals shows that the actual use of information technology is positively related to performance. The higher the level of actual use of information technology, the better the financial performance and quality of the hospital.

Aral and Weill (2007) suggest that the difference in the performance of two organizations that have the same amount of information technology investment lies in the difference in the type of technology invested and its objectives. Their study found that investing in a certain type of information technology will result in higher performance only on dimensions consistent with the strategic objectives of the technology. For example, investment in transactional applications of information technology that aims to reduce cost standards, repetitive processes, results in reduced costs, but does not impact on the company's product 
The Interaction of Institutionalization of Information Technology \& Institutional

Entrepreneurship: An Idea of a Framework for the Application of Information Technology in Public Sector Financial Management

innovations. These innovations can only be obtained if the investment is directed at more strategic applications, but they are not associated with lower costs.

Information technology independently will not have any meaning, until it is used in organizational routines. However, the impact is determined by how technology interacts with users in routine organizational practices ( Orlikowski, 2000 ). These interactions can be in the form of implementing the initial design and technology structure, or adjusting to user conditions, so that it has an impact on the end result of using technology. Because technology is a resource that can be formed for various uses (with various consequences) depending on the choice of strategy or ideology ( Feldman \& Orlikowski, 2011). The benefits obtained by the organization really depend on what strategic role is played by information technology in the organization. These strategic roles can be in the form of using information technology for automating old routines (Automate), providing information that is used for process improvement (Informate), to transforming old routines (Dehning et al., 2003). The study of K. Kobelsky, Larosiliere, and Plummer (2014) on the use of information technology in public sector institutions proves that the more strategic the routine of using information technology, namely informating or transforming, the more positive its impact on performance. Transformation shows a more strategic level of use, the organization must make changes and internalize these changes into new routines. If the change can be implemented into a new routine, it will have a higher impact on the organization than the other two approaches.

Extensive use of technology allows for increased accountability of regional financial management processes. The performance-based budgeting process is more effective, because all documented budget proposals can be evaluated on performance targets quickly. Budget use control can be carried out effectively, due to the availability of budget data that can be accessed at any time. All transactions can be immediately documented, thus guaranteeing the preparation of financial and performance reports in accordance with applicable regulations.

The performance of regional financial management can be further improved, if the use of information technology is broader, including transparency and public participation practices. The role of information technology is more coherent, including automating accountability practices, expanding information transparency and facilitating public involvement to improve local financial management processes. If the transformation of old practices can be carried out, then the impact obtained can be seen in the performance of every aspect of the regional financial management cycle which includes planning and budgeting, budget execution and administration, to reporting and evaluation of budget use. If the transformation is not carried out, then the routine formed will only include automation of the old routine, which indicates that the values of transparency and partitioning are not actualized as a whole in the new regional financial management routine, so that the regional financial management performance achieved is partial or only involves certain aspects. of the organization.

The more extensive use of information technology, which is reflected in the scope of its use in all regional financial management processes, and includes transparency and public participation practices, makes these processes more effective. The extensive use of information technology allows for an increase in the quality of the stipulated budget, facilitates more effective control of budget execution, produces accountability in accordance with statutory provisions, thereby enabling an increase in the overall performance of regional financial management. 
In addition, the wider the dimension of information technology legitimacy, the more likely it is that information technology will be implemented and maintained in various regional financial management practices, and eventually internalized in the entire regional financial management process. Internalized information technology practices indicate that information technology is an important part of carrying out regional financial management processes effectively, so that the possibility of realizing technical benefits is greater.

Apart from the legitimacy aspect, resources also play a role in the institutionalization process. The mobilized resources become the driving force for the continuity of implementing a new practice, until it is internalized into a routine that has an impact on the organization. Barley and Tolbert (1997) argued that institutional change might occur when actors follow routine behaviors, but when accompanied by strong motivation and active participation in the change process, institutional change can occur more quickly. This conclusion is in accordance with the study of Lawrence et al. (2002) who concluded that mobilization through equal collaborative arrangements between participants, can drive broad institutional change. The wide and deep scope of interaction between participants, as well as sharing of experiences, can overcome the complexity of the problem together, and produce a more coherent process of institutionalizing new practices, technology and rules. The relationships that are formed allow the process of legitimizing new practices, technology and regulations to take place more quickly. Thus facilitating the mobilization of strategically owned resources will facilitate the process of change in a broad and sustainable manner, including in applying information technology in the financial management of local governments.

\section{CONCLUSION}

Institutionalization should indicate that the use of information technology has become routine in regional financial management processes. This routine should have a positive impact on the performance of regional financial management. The discretion held by institutional actors allows for variations in the legitimacy of information technology practices among local governments. Different interests allow variations in mobilizing resources to carry out information technology practices. Although information technology has all the technical features needed to support better regional financial management activities, different usage routines can have different impacts. Fully institutionalized information technology indicates the use of all potential information technology in the entire scope of regional financial management activities, so that it has a more optimal impact.

Information technology practices that are supported by resources have a higher likelihood of surviving and developing. The wider the mobilization of human resources and budgets in information technology practices, the wider the use of information technology in regional financial management practices, so that it is internalized in regional financial management processes. Internalized information technology practices indicate that information technology is an important part of carrying out regional financial management processes effectively, so that the possibility of realizing technical benefits is greater. Likewise, if it is supported by intense resource mobilization in all regional financial management processes, including transparency and public participation practices, the more extensive information technology is used for these practices, and the more likely it is to achieve improved local financial management performance.

Therefore, based on Tolbert and Zucker (1996) which states that an important issue that must be studied related to institutionalization is the determinants of variations in the level of institutionalization and how the impact of these variations on a group of similar organizations in the environment is to get an overview of the actual implementation conditions, further 
The Interaction of Institutionalization of Information Technology \& Institutional

Entrepreneurship: An Idea of a Framework for the Application of Information Technology in Public Sector Financial Management

research on the application of information technology in the public sector is not only limited to analyzing the effect of institutionalization of information technology on the performance of regional financial management but also needs to consider the moderating effect of the activities of institutional actors who can interact with the institutionalization process, especially related to mobilization mechanisms and legitimacy dynamics.

\section{REFERENCES}

[1] Aldrich, HE, \& Fiol, CM (1994). Fools rush in? The Institutional context of industry creation. The Academy of Management Review, 19 (4).

[2] Anggriawan, FT, \& Yudianto, I. (2018). Factors Affecting Information Quality of Local Government Financial Statement. Journal of Accounting Auditing and Business, 1 (1), 30-42.

[3] Aral, S., \& Weill, P. (2007). IT Assets, Organizational Capabilities, and Firm Performance: How Resource Allocations and Organizational Differences Explain Performance Variation. Organization Science, 18 (5), 763 - 780.

[4] Ashforth, BE, \& Gibbs, BW (1990). The Double-edge of organizational legitimation. Organization Science, 1 (2), 177 - 194.

[5] Avgerou, C. (2000). IT and organizational change: an institutionalist perspective. Information Technology \& People, 13 (4), 234-262.

[6] Avgerou, C. (2004). IT as an institutional actor in developing countries. In S. Krishna \& S. Madon (Eds.), The digital challenge: information technology in the development context (pp. 46 - 62). Aldershot, UK: Ashgate Publishing.

[7] Backhouse, J., Hsu, CW, \& Silva, L. (2006). Circuits of Power in Creating De Jure Standards: Shaping an international information systems security standard. MIS Quarterly, 30 , 413-438.

[8] Barley, SR (2008). Coalface Institutionalism. In R. Greenwood, C. Oliver, K. Sahlin \& R. Suddaby (Eds.), The SAGE handbook of organizational institutionalism (pp. 491 518). London: SAGE Publication Ltd.

[9] Barley, SR, \& Tolbert, PS (1997). Institutionalization and Structuration: Studying the Links Between Action and Institution. Organization Studies, 18 (1), 93-117.

[10] Berger, P., \& Luckman, T. (1967). Social Construction of Reality . New York: Anchor Books.

[11] Brynjolfsson, E., \& Hitt, LM (2000). Beyond Computation: Information Technology, Organizational Transformation and Business Performance. Journal of Economic Perspectives, $14(4), 23-48$.

[12] Carter, N., Klein, R., \& Day, P. (1992). How Organizations Measure Success: The Use of Performance Indicators in Government . London: Routledge.

[13] Cohen, MD, \& Bacdayan, P. (1994). Organizational Routines Are Stored as Procedural Memory: Evidence from a Laboratory Study. Organization Science, 5 (4), 479-625.

[14] Cousins, KC, \& Robey, D. (2005). The social shaping of electronic metals exchanges: an institutional theory perspective. Information Technology \& People, 18 (3), 212 - 229. 
[15] Covaleski, MA, \& Dirsmith, MW (1988). An Institutional Perspective on the Rise, Social Transformation, and Fall of a University Budget Category. Administrative Science Quarterly, $33(4), 562-587$.

[16] Currie, WL (2004). The Organizing Vision of Application Service Provision: a processoriented analysis. Information and Organization, 14 (4), 237-267.

[17] Dacin, MT, Goodstein, J., \& Scott, WR (2002). Institutional Theory and Institutional Change: Introduction to the Special Research Forum. Academy of Management Journal, 45 (1), 45-57.

[18] Dambrin, C., Lambert, C., \& Sponem, S. (2007). Control and Change: Analyzing the Process of Institutionalization. Management Accounting Research, 18 (2), 172-208.

[19] Dehning, B., Richardson, VJ, \& Zmud, RW (2003). The Value Relevance of Announcements of Transformational Information Technology Investments. MIS Quarterly, 27 (4), 637 - 656.

[20] Devaraj, S., \& Kohli, R. (2000). Information Technology Payoff in the Health-Care Industry: A Longitudinal Study. Journal of Management Information Systems, 16 (4), 41 - 67.

[21] Devaraj, S., \& Kohli, R. (2003). Performance Impacts of Information Technology: Is Actual Usage the Missing Link? Management Science, 49 (3), 273 - 289.

[22] DeVaujany, F.-X., Carton, S., Mitev, N., \& Romeyer, C. (2014). Applying and theorizing institutional frameworks in IS research: A systematic analysis from 1999 to 2009. Information Technology \& People, 27 (3), 280-317.

[23] Dillard, JF, Rigsby, JT, \& Goodman, C. (2004). The making and remaking of organization context: Duality and the institutionalization process. Accounting, Auditing \& Accountability Journal, 17 (4), 506 - 542.

[24] DiMaggio, PJ, \& Powell, WW (1983). The iron cage revisited: institutional isomorphism and collective rationality in organizational fields. American Sociological Review, 48, 147-160.

[25] Dorado, S. (2005). Institutional entrepreneurship, partaking, and convening. Organization Studies, 26 (3), 385 - 414.

[26] Dorotinsky, W., \& Watkins, J. (2013). Government Financial Management Information Systems. In R. Allen, R. Hemming \& BH Potter (Eds.), The International Handbook of Public Financial Management (pp. 797 - 816). London: Palgrave Macmillan.

[27] Dowling, J., \& Pfeffer, J. (1975). Organizational Legitimacy: Social Values and Organizations. The Pacific Sociological Review, 18 (1), 122-136.

[28] Earl, MJ (1992). Putting IT in its place: a polemic for the nineties. Journal of Information Technology, 7 (2), 100 - 108.

[29] Edquist, C., \& Johnson, B. (1997). Institutions and organizations in systems of innovation. In C. Edquist (Ed.), Systems of Innovation: Technologies, Institutions and Organizations (pp. 41 - 63). New York: Routledge.

[30] El-Haddadeh, R., Weerakkody, V., \& Al-Shafi, S. (2013). The Complexities of Electronic Services Implementation and Institutionalization in The Public Sector. Information \& Management, 50 (4), 135-143. 
The Interaction of Institutionalization of Information Technology \& Institutional Entrepreneurship: An Idea of a Framework for the Application of Information Technology in Public Sector Financial Management

[31] Etzioni, A. (1968). Mobilization as a Macrosociological Conception. The British Journal of Sociology, 19 (3), 243 - 253.

[32] Feldman, MS, \& Orlikowski, WJ (2011). Theorizing practice and practicing theory. Organization Science, 22 (5), 240-253.

[33] Fligstein, N. (1997). Social Skill and Institutional Theory. American Behavioral Scientist, 40 (4), 397 - 405.

[34] Fligstein, N. (2001). The architecture of markets: an economic sociology of twenty-firstcentury capitalist societies. New Jersey: Princeton University Press.

[35] Frumkin, P., \& Galaskiewicz, J. (2004). Institutional Isomorphism and Public Sector Organization. Journal of Public Administration Research and Theory, 14 (3), 283-307.

[36] Furqan, AC, Wardhani, R., Martani, D. and Setyaningrum, D. (2020), "The effect of audit findings and audit recommendation follow-up on the financial report and public service quality in Indonesia", International Journal of Public Sector Management, Vol. 33 No. 5, pp. 535-559.

[37] Gosain, S. (2004). Enterprise Information Systems as Objects and Carriers of Institutional Forces: The New Iron Cage? Journal of the Association for Information Systems, 5 (4), 151182.

[38] Granovetter, M. (1985). Economic action and social structure: The Problem of embeddedness. American Journal of Sociology, 91 (3).

[39] Greenfield, G., \& Rohde, F. (2009). Technology acceptance: Not all organizations or workers may be the same. International Journal of Accounting Information Systems, 10 (4), 263-272.

[40] Greenwood, R., Hinings, CR, \& Whetten, D. (2014). Rethinking institutions and organizations. Journal of Management Studies, 51 (7), 1206 - 1220.

[41] Greenwood, R., Oliver, C., Sahin, K., \& Suddaby, R. (2008). Introduction The SAGE handbook of Organizational institutionalism . London: SAGE Publications Ltd.

[42] Hannan, MT, \& Freeman, J. (1986). Where Do Organizational Forms Come From? Sociological Forum, 1 (1), 50 - 72.

[43] Hasselbladh, H., \& Kallinikos, J. (2000). The Project of Rationalization: A Critique and Reappraisal of Neo-Institutionalism in Organization Studies. Organization Studies, 21 (4), 697-720.

[44] Hazlett, S.-A., \& Hill, F. (2003). E-government: the realities of using IT to transform the public sector. Managing Service Quality, 13 (6), 445 - 452.

[45] Heeks, R. (2002). Information System and Developing Countries: Failure, Success, and Local Improvisation. The Information Society, 18 (2), 101-112.

[46] Heeks, R. (2003) Most eGovernment-for-Development Project Fail: How Can Risks be Reduced? , iGovernment Working Paper . Manchester, UK: Institute for Development Policy and Management, University of Manchester. 
[47] Heinrich, CJ (2003). Measuring Public Sector Performance and Effectiveness. In BG Peters \& J. Pierre (Eds.), Handbook of Public Administration (pp. 25 - 37). Thousand Oaks, CA: Sage Publication Ltd.

[48] Ho, A. (2007). The Governance Challenges of the Government Performance and Results Act: A Case Study of the Substance Abuse and Mental Health Administration. Public Performance \& Management Review, 30 (3), 369 - 397.

[49] Huntington, SP (1965). Political development and political decay. World Politics, 17 (3), 386 430 .

[50] Jauhari, H., Sari, Y., \& Dewata, E. (2019). Implementation of good governance, utilization of information technology and reliability of government financial statement. Journal of Accounting and Strategic Finance, 2 (2), 117 - 126.

[51] Jepperson, RL (1991). Institutions, institutional effects, and institutionalism. In WW Powell \& PJ DiMaggio (Eds.), The New institutionalism in Organizational Analysis (pp. 143 163). Chicago: The University of Chicago Press.

[52] Jones, M. (2000). The Moving Finger: The Use of Social Theory in WG 8.2 Conference Papers, 1975-1999. In R. Baskerville, J. Stage \& JI DeGross (Eds.), Organization and Social Perspectives on Information Technology(pp. 1-12). Boston, MA: Kluwer Academic Publisher.

[53] Jordan, MM, \& Hackbart, M. (2005). The goals and implementation success of state performance-based budgeting. Journal of Public Budgeting, Accounting \& Financial Management, 17 (4), 471 - 487.

[54] Kaganer, E., Pawlowski, SD, \& Wiley-Patton, S. (2010). Building legitimacy for IT innovations: The Case of computerized physician order entry systems. Journal of the Association for Information Systems, 11 (1), 1 - 33.

[55] Katsikas, E., Rossi, FM, \& Orelli, RL (2017). Accounting change: integrated reporting through the lenses of institutional theory Towards Integrated Reporting : Springer, Cham.

[56] Kling, R., \& Lacono, S. (1989). The Institutional Character of Computerized Information Systems. Office Technology and People, 5 (1), 7 - 28.

[57] Kobelsky, K., Larosiliere, G., \& Plummer, E. (2014). The impact of information technology on performance in the not-for-profit sector. International Journal of Accounting Information Systems, 15, 47-65.

[58] Kostova, T., \& Roth, K. (2002). Adoption of an organizational practice by subsidiaries of multinational organizations: institutional and relational effects. Academy of Management Journal, 45 (1), 215-233.

[59] Kumar, R., \& Best, ML (2006). Impact and Sustainability of E-Government Services in Developing Countries: Lessons Learned from Tamil Nadu, India. The Information Society, $22(1), 1-12$.

[60] Laudon, KC (1985). Environmental and institutional models of system development: a national criminal history system. Communications of the ACM, 28, 728 - 740. 
The Interaction of Institutionalization of Information Technology \& Institutional

Entrepreneurship: An Idea of a Framework for the Application of Information Technology in Public Sector Financial Management

[61] Lawrence, TB, Hardy, C., \& Phillips, N. (2002). Institutional Effects of Interorganizational Collaboration: The Emergence of Proto-Institutions. Academy of Management Journal, 45 (1), 281-290.

[62] Maguire, S., Hardy, C., \& Lawrence, TB (2004). Institutional Entrepreneurship in Emerging Fields: HIV / AIDS Treatment Advocacy in Canada. Academy of Management Journal, 47 (5), $657-679$.

[63] Mark, AL (2007). Modernizing healthcare - is the NPfIT for purpose? Journal of Information Technology, 22 (3), 248 - 256.

[64] May, CR, \& Finch, T. (2009). Implementing, Embedding, and Integrating Practices: An Outline of Normalization Process Theory. Sociology, 43 (3), 535 - 554.

[65] Meyer, JW, \& Rowan, B. (1977). Institutionalized organizations: formal structure as myth and ceremony. The American Journal of Sociology, 83 (2).

[66] Mignerat, M., \& Rivard, S. (2009). Positioning the institutional perspective on information systems research. Journal of Information Technology, 24 (4), 369-391.

[67] Miscione, G. (2007). Telemedicine in the Upper Amazon: Interplay with local health care practices. MIS Quarterly, 31 (2), 403-425.

[68] Modell, S. (2003). Goals Versus Institutions: the development of performance measurement in the Swedish university sector. Management Accounting Research, 14, 333-359.

[69] Muda, I., Wardani, DY, Erlina, Maksum, A., Lubis, AF, Bukit, R., \& Abubakar, E. (2017). The influence of human resources competency And the use of information technology on the Quality of local government financial report With regional accounting system as an Intervening. Journal of Theoretical and Applied Information Technology, 95 (20), 5552 5561.

[70] Oliver, C. (1991). Strategic Responses to Institutional Processes. The Academy of Management Review, 16 (1), 145-179.

[71] Oliver, C. (1992). The Antecedents of Deinstitutionalization. Organization Studies, 13 (4), 563-588.

[72] Oliver, C. (1997). Sustainable Competitive Advantage: Combining Institutional and ResourceBased View. Strategic Management Journal, 18 (9), 697-713.

[73] Orlikowski, WJ (2000). Using Technology and Constituting Structures: A Practice Lens for Studying Technology in Organizations. Organization Science, 11 (4), 404 - 428.

[74] Orlikowski, WJ, \& Barley, SR (2001). Technology and Institutions: What can research on information technology and research on organizations learn from each other? MIS Quarterly, $25(2), 145-165$.

[75] Parsons, T. (1991). The Social System . London: Routledge.

[76] Peterson, S. (2006). Automating Public Financial Management in Developing Countries John F.Kennedy School of Government Working Paper : Harvard University. 
[77] Powell, WW, \& Dimaggio, PJ (1991). The New Institutionalism in Organizational Analysis . Chicago: University of Chicago Press.

[78] Rahman, A., \& Fachri, Z. (2016). Region's Financial Accounting Information System and the Quality of Local Government Financial Reports. Information Management and Business Review, 8(4), 64 - 68.

[79] Rao, H. (1998). Caveat emptor: The Construction of nonprofit consumer watchdog organizations. American Journal of Sociology, 103 (4), 912 - 961.

[80] Rao, H., \& Giorgi, S. (2006). Code breaking: How entrepreneurs exploit cultural logics to generate institutional change. Research in Organizational Behavior, 27, 269 - 304.

[81] Rao, H., Morrill, C., \& Zald, MN (2000). Power plays: How social movements and collective action create new organizational forms. Research in Organizational Behavior, 22 , 237 - 281.

[82] Robey, D., \& Boudreau, M.-C. (1999). Accounting for the contradictory organizational consequences of information technology: theoretical directions and methodological implications. Information Systems Research, 10 (2), 167 - 185.

[83] Scott, WR (1995). Institution and organization . Thousand Oaks, Calif: Sage.

[84] Scott, WR (2005). Institutional Theory: Contributing To A Theoretical Research Program. In KG Smith \& MA Hitt (Eds.), Great Minds In Management: The Process Of Theory Development (pp. 460-484). Oxford UK: Oxford University Press.

[85] Scott, WR (2014). Institutions and Organizations - Ideas, Interests, and Identities (4th ed.). USA: SAGE Publications, Inc.

[86] Seo, M.-G., \& Creed, WED (2002). Institutional Contradictions, Praxis, and Institutional Change: A Dialectical Perspective. Academy of Management Review, 27 (2), 222 - 247.

[87] Siti-Nabiha, AK, \& Scapens, RW (2005). Stability and change: an institutionalist study of management accounting change. Accounting, Auditing \& Accountability Journal, 18(1), 4473.

[88] Suchman, MC (1995). Managing legitimacy: Strategic and institutional approaches. academy of Management Review, 20 (3), 571 - 610.

[89] Suddaby, R. (2010). Challenges for Institutional Theory. Journal of Management Inquiry, $19(1), 14-20$.

[90] Swanson, EB, \& Ramiller, NC (1997). The Organizing Vision in Information Systems Innovation. Organization Science, 8 (5), 458-474.

[91] Teo, HH, Wei, KK, \& Benbasat, I. (2003). Predicting Intention to Adopt Interorganizational Linkages: An Institutional Perspective. MIS Quarterly, 27 (1), 19-49.

[92] Tolbert, PS, \& Zucker, LG (1996). The Institutionalization of Institutional Theory. In SR Clegg \& C. Hardy (Eds.), Studying Organization - Theory and method (pp. 169-184). London: Sage Publications.

[93] UNDESA. (2014). E-Government survey 2014 - E-Government for the future we want. New York: United Nations. 
The Interaction of Institutionalization of Information Technology \& Institutional Entrepreneurship: An Idea of a Framework for the Application of Information Technology in Public Sector Financial Management

[94] Ven, AHV d., \& Drazin, R. (1984). The concept of fit in contingency theory. Research in Organizational Behavior, 7 , 333-365.

[95] Ven, AHV d., \& Garud, R. (1993). Innovation and industry development: The Case of cochlear implants. Research on Technological Innovation, Management and Policy, 5 , 1 - 46.

[96] Venkatraman, N. (1989). The concept of fit in strategy research: toward verbal and statistical correspondence. Academy of Management Review, 14 (3), 423-444.

[97] Verbeeten, FHM (2008). Performance management practices in public sector organizations: Impact on performance. Accounting, Auditing \& Accountability Journal, 21 (3), 427 - 454.

[98] Wang, P., \& Swanson, EB (2007). Launching of professional services automation: Institutional entrepreneurship for information technology innovations. Information and Organization, $17,59-88$.

[99] Wang, P., \& Swanson, EB (2008). Customer relationship management as advertised: Exploiting and sustaining technological momentum. Information Technology \& People, $21(4), 323-349$.

[100] Weerakkody, V., Dwiyedi, YK, \& Irani, Z. (2009). The Diffusion and Use of Institutional Theory: a cross-disciplinary longitudinal literature survey. Journal of Information Technology, 24 (4), 354-368.

[101] Winter, SG (2003). Understanding dynamic capabilities. Strategic Management Journal, 24 (10), 991-995.

[102] Yeh, JY, \& OuYang, Y.-C. (2010). How an organization changes in ERP implementation: a Taiwan semiconductor case study. Business Process Management Journal, 16 (2), 209 - 225.

[103] Yuliani, NL, \& Agustini, RD (2016). Factors affecting the quality of local government financial statements. Journal of Business \& Economics, 14 (1), 56-64. 